\title{
ASSESSMENT OF THE ACTIVITY EFFECTIVENESS OF THE NATIONAL POLICE OF UKRAINE TO PROVIDE PUBLIC SECURITY IN THE CONDITIONS OF THE UNITED FORCES OPERATIONS
}

\author{
Abroskin V. V.
}

\section{INTRODUCTION}

Ensuring public order and public security in the state by the National Police of Ukraine, combating crime, protecting the rights, freedoms and interests of citizens is an important element of public administration.

The creation of the National Police of Ukraine raised the question of the introduction of a new modern approach, which would give an objective idea of the level of effectiveness of its activities. Performance appraisal, encompassing the activities of police bodies and units, including in the event of circumstances of a specific nature, such as the united forces operations, is extremely important as it directly influences the determination of the directions and priorities of administration, allows to ensure sufficient level of efficiency of this law enforcement agency and increase the already existing indicators.

Determining the level of effectiveness of police activities allows you to objectively evaluate the work of the latter, to make effective management decisions, which is especially relevant in the area of the united forces operations, where the mistake of a leader can cost more than one human life. The assessment process is compounded by the specific situation that requires every police officer to do his utmost and to work outside of his or her daily routine. In such circumstances, the issue of developing an effective and objective mechanism for evaluating the effectiveness of the police as a whole, and in particular, becomes even more urgent, especially given that today the general mechanism for conducting such an evaluation is not fully formed, but in the presence of specific conditions it is should be carried out taking into account the peculiarities of the situation in which the police have to work every day.

The Law of Ukraine "On National Police" stipulates that police activity should be aimed at meeting the needs of the population, and its level of trust in the police is one of the main criteria for evaluating the effectiveness of the activities of police bodies and units. However, these questions regarding the overall performance evaluation of the police and its units have been identified unilaterally, only within the framework of public assessment. 
In particular, in Part 3 of Art. 11 of the Law of Ukraine "On the National Police" states that the main criterion for assessing the effectiveness of the police is the level of public confidence ${ }^{1}$. The level of public trust in the police is based solely on their subjective understanding of how the police should work and what means to use. In almost all cases, such an assessment is fundamentally different from the reality, in particular because of the ignorance of the majority of the population in the legal rules governing police activity.

Determining the level of citizens' trust in the police as the main indicator of the work of the National Police, although it is a rather progressive and modern step within the reform of law enforcement agencies, but today, in the context of numerous reforms and ambiguous political and economic situation affecting the overall psycho-emotional background society, it is appropriate to take into account not a single indicator, but a set of quantitative and qualitative indicators.

Thus, assessing the level of public confidence in the bodies and units of the National Police allows to identify problematic issues in their activities, take into account the public opinion to improve their work, which contributes to the efficiency of the bodies and units of the police, makes their activities more transparent, understandable and controlled society.

\section{Indicators of assessment of the efficiency of the National Police work}

The activities of the National Police in the area of public security and order are one of the areas of public administration. Therefore, it is necessary to find out the meaning of the relevant category in the system connection with the government. In the dictionary, the category "efficiency" is defined as: 1) a differentiated and multilevel characteristic, which at the same time retains its relativity with respect to the declared goals; 2) the relationship between the product and the resources that went into creating it in terms of the result, that is, the connection with the resources, the product and the goals, but necessarily with the effect, the latter being achieved outside the activity, process of creating the product or service, in the process of its consumption ${ }^{2}$. Thus, the main content of the category "efficiency" is revealed by the ratio of tasks, results and means (resources)

\footnotetext{
1 Про Національну поліцію: Закон України від 02 липня 2015 р. № 580-VIII. URL: https://zakon.rada.gov.ua/laws/show/580-19 (дата звернення: 22.01.2020).

2 Великий тлумачний словник сучасної української мови / уклад. і голов. ред. В.Т. Бусел. Київ ; Ірпінь : Перун, 2009. 1736 с.
} 
spent on it. Meanwhile, the results of management activities that do not involve the formation (production) of a tangible object, should be evaluated taking into account certain features of measuring its effectiveness.

The scientific literature offers various definitions of the category of "public administration efficiency". Scientist V. Malikov provided definition of efficiency of activity of units of public safety militia on protection of public order in public places and ensuring of safety of citizens as a correlation between actual result of their activity (consistency of actions of subjects of public order and security of citizens, number of drawn up administrative protocols, detained violators of public order, held meetings with the population and representatives of public formations, etc.) and those goals and objectives that are facing these units in the field of public order ${ }^{3}$, which in formulating this definition, proceeded from a broad understanding of the concept of "efficiency". A more narrow (specific) approach involves the identification of several separate elements of efficiency, in particular, resource-saving, economic, social, target component, etc.

According to $\mathrm{O}$. Tkachova public administration efficiency is the achievement of socially significant results at socially justified costs. Public administration efficiency is a complex concept that depends on many factors, including economic, social, political, organizational, and so on. Therefore, the scientist considers it necessary to introduce an individual approach to each management object and to develop an individual system of criteria and indicators for evaluating the effectiveness of the functioning of the public administration ${ }^{4}$. The opinion of the scientist should be agreed, because each body has its own tasks and therefore it is not possible to evaluate the effectiveness of their results.

Thus, the signs of the effectiveness of providing public security and order by the National Police in the state include: being part of the overall effectiveness of the National Police; reflects the actual state of organization and management of the work of the police in the appropriate direction, in which the goals are achieved and the corresponding tasks are performed in combination with the most optimal use of resources (financial, human resources, etc.); effectiveness is influenced by various factors of economic, social, legal, organizational and other nature. Therefore, when assessing it, it is necessary to take a comprehensive approach to determining the criteria.

\footnotetext{
3 Маліков В.В. Адміністративно-правові форми забезпечення громадського порядку. Серія Право. 2014. Вип. 28. Т. 2. С. 144-147.

4 Ткачова О.К. Ефективність державного управління: поняття та підходи до оцінювання. Вісник Національної академії державного управління при Президентові Украӥни. 2013. № 2. C. 30-37. URL: http://nbuv.gov.ua/UJRN/Vnadu_2013_2_6 (дата звернення: 26.12.2019).
} 
Effectiveness of providing public security and order in the state by the National Police of Ukraine can be defined as the level of quantitative results of the police activity, which are expressed in the achievement of a proper state of protection of vital interests, which are included in the content of public security and order, through the optimal use of methods, means and resources for these purposes.

As rightly note O. Martynenko and E. Zakharov, citizens should be sure that police personnel are "skilled in law enforcement activities in crime prevention, crime detection and public order protection; honestly performs its duties and complies with the law; helps ordinary people; treats all people with respect"'.

The work of I. Okhrimenko is particular importance, which stated that the proper assessment of the effectiveness of the activities of bodies and units of the National Police of Ukraine should be determined by the following components: 1) indicators of the appointment and immediate primary activity of the authorized entities; 2) indicators of public safety and order; 3) reliability indicators; 4) indicators of the professional level of police personnel; 5) optimizing the use of resources; 6) the total percentage of the population satisfied with the quality of work of police bodies and units ${ }^{6}$.

In particular, the first indicator assesses the timeliness of the implementation of various necessary measures by police, including those related to responding to citizens' statements and their satisfaction with the result of the decision, as well as the congruence (adequacy) and cooperation of police services and units.

The second indicator combines quantitative and qualitative information on registered individual types of offenses (criminal and administrative) per 1 thousand inhabitants of the service territory and as a percentage the number of investigated (uncovered), the implementation of preventive activities by the police, which reflects the perception of each person crime level.

The third indicator (reliability) summarizes the results of the police services provided: from the number of complaints to the notification of citizens about the decisions taken on the complaints.

\footnotetext{
5 Мартиненко О., Захаров $Є$. Стратегія розвитку органів внутрішніх справ. Закон $і$ Бізнес. URL: http://zib.com.ua/ua/print/101834-strategiya_rozvitku_organiv_vnutrishnih_sprav_ tekst_proektu.html (дата звернення: 01.12.2019).

Охріменко I.M. Оцінка ефективності діяльності органів і підрозділів Національної поліції України: погляд на проблему. Підприємництво, господарство і право. 2016. № 11. C. $139-144$.
} 
The fourth indicator (professional level of police personnel) represents the level of professionalism of police personnel by assessing the number of working professionals, their level of training, skills, knowledge, skills and information, the objective need for their retraining, as well as their moral and business qualities (eg, humanity and benevolence).

The fifth indicator assumes that in the process of resource optimization, the logistics of the police is assessed on certain issues: information, technical, transport and financial support, etc.

The sixth indicator creates an idea of the population of the country, which is generally satisfied with the work of the National Police, by assessing precisely the level of trust of the population and covers "various forms of gathering information on complaints and complaints from citizens; procedure for evaluating this reaction in different cases (situations); the system of response measures taken (promotion and punishment); overall evaluation of the work of the structural unit or police body; the amount of public information available; evaluation of professional training of police personnel, etc"?.

The disparity of these indicators, which, in our opinion, most fully characterize police activity and form a real objective view of the performance of the tasks assigned to the police, requires the development of versatile assessment approaches, that is, the systematic use of appropriate tools to assess the effectiveness of police through the use of empirical research methods (observation, experiment, comparison, measurement, survey, description) ${ }^{8}, 9$ to collect the necessary data and theoretical (analysis, synthesis, induction, deduction, etc.) - to obtain relevant conclusions on police performance.

\section{Methods of assessing the efficiency of the National Police work}

An important theoretical component of evaluating police activity is the method of evaluation. It is worth agreeing with the opinion of U. Danilenko, which states that the methods are usually used in theoretical studies, and the methods are used in practical activities. Thus, a derivative of the term "method" is a concept of "methodology" that specifies

\footnotetext{
7 Основи методології та організації наукових досліджень : навчальний посібник / за ред. А.С. Конверського. Київ : Центр навч. літ., 2010. 352 с.

8 Пчелін В.Б. Сутність інформаційного забезпечення адміністративного судочинства України. Науковий вісник Ужгородського національного університету. Серія «Право». 2016. Вип. 3. Т. 2. С. 22-25.

9 Рассоха I.М. Методологія та організація наукових досліджень: конспект лекцій. Харків : Харків. нац. акад. міськ. госп-ва, 2011. 76 с.
} 
a particular method in the form of a procedure, sequence of actions, rules, or instructions.

Generally speaking, a method is a set of methods, approaches, and techniques that allow one to obtain and learn the necessary information about a research object. Instead, the methodology for evaluating police activity is the totality and consistency of using various techniques and techniques to investigate the effectiveness and efficiency of service, personal and business qualities, health and physical fitness of police officers.

The choice of one method or another depends on the social relationships being investigated and the outcome expected. Therefore, assessment methods are more effective and efficient when used in combination of several methods at the same time, which are collectively capable of exploring an object or subject from different sides, by different criteria ${ }^{10}$.

We describe the methods by which police performance can be assessed.

We use the observation method (both by specialists and ordinary citizens) to study the work of police departments or individual police officers, which excludes any activity by which one can form an idea of the actual day-today work of the police without "any embellishments and exaggerations".

The experiment method is advisable to apply new measures to the work of police units immediately before directly implementing them, in order to find out how they will affect police performance or to identify the potential capacity of police officers in complex, ambiguous and specific conditions.

In turn, the work of individual police units or territorial and police departments within one or different regions can be compared, which will give an idea of the difference in the level of effectiveness of certain police agencies to find out the positive aspects of the work to be undertaken or vice versa. negative ones - to eliminate them.

The measurement method is associated with obtaining various kinds of quantitative indicators for further processing, for example for statistical purposes. Under these conditions, a number of elements are required: a directly measurable object; the quantities by which it is carried out; the method of measurement is determined and directly by the person (group of persons) who performs it.

The most relevant of the methods by which primary information is collected is the survey method: it is used either directly during the interview process or indirectly through questionnaires. One of the features of the survey, regardless of the form in which it is conducted, is that the data is obtained

10 Аброськін В.В. Особливості організації служби на блокпостах у зоні антитерористичної операції. Науковий вісник публічного та приватного права. 2018. Вип. 5. С. 125-129. 
in the form in which it is displayed in the minds of persons participating in it, and therefore it is necessary to take into account that the information received may be somewhat distorted by subjective factors and personal perception of each person's life realities. The survey can be used to as clearly as possible examine the general public opinion about the quality of work of the National Police and the crime rate in the country or in its individual territory. An extremely important aspect in this case should be the interviewing of persons who, for one reason or another, have had direct contact with the police, as such information may give a more complete picture of work of the police ${ }^{11}$.

In order to obtain information on internal organizational processes and problematic issues, it is necessary to interview not only citizens but also directly police officers, which will allow to identify organizational, administrative and service issues.

The qualitative method is applied in conjunction with such methods as: 1) method of observation - evaluation of police behavior in both office and non-business hours, carried out by direct or direct manager; 2) matrix - is based on a comparison of the direct manager of actual results of the performance of functional duties, professional qualities (characteristics) of the police officer with the list of those defined in the job description; 3) standard assessments - involves filling in a direct or direct manager of a police special form - an attestation letter, which analyzes and evaluates certain aspects of the activity of a subordinate employee during the reporting period ${ }^{12}$.

The description, as a final method, is used by the direct supervisor in the overall assessment of a police officer by various criteria: 1) performance results in accordance with functional responsibilities; discipline, principle in dealing with service issues, the ability to build relationships with citizens and colleagues, the ability to work to eliminate personal shortcomings, authority in the team and among the population; 2) aspiration to improve service, sense of personal responsibility, stability of moral principles, courage, determination, organization, ability to control one's own emotions, behavior outside the service; 3) knowledge of foreign languages; culture in service and attitude to improve their educational and cultural levels; 4) health and physical fitness, ability to possess a firearm,

\footnotetext{
11 Адміністративна діяльність органів внутрішніх справ. Загальна частина : навчальний посібник / В.В. Середа та ін. Львів : Львів. держ. ун-т внутр. справ, 2015. 511 с.

12 Адміністративна діяльність Національної поліції : навчальний посібник / Т.П. Мінка та ін. Дніпро : Дніпроп. держ. ун-т внутр. справ, 2017. 248 с.
} 
hand-to-hand combat techniques, special personal protective equipment and active defense; 5) the main most significant deficiencies in service and personal behavior; 6) other data which, in the opinion of the manager, deserve attention for a more complete description of the subordinate; 7) results of training $\left.{ }^{13},{ }^{14}\right)$; this method provides a consistent and reasoned characterization of the performance of each police officer, identifying both advantages and disadvantages.

Further work with the received primary information should be based on the use of methods of analysis, synthesis, induction, deduction and others.

The analysis allows us to examine the overall performance of the police by examining the performance of its individual services and units, which are then combined to provide a general study using the synthesis method.

Using the induction method, it is possible to investigate the factors that adversely affect the work of police, by identifying them in a separate set of police departments and services where they occur, and further generalizing them to a larger number of police bodies.

Deduction can allow you to draw a logical conclusion, moving from "general to individual", thus first examining the whole object - the body or police department, and then detailing its constituent elements, that is, first of all, to study the overall level of efficiency, and then each structural unit. As a result of applying this method, it is possible to conclude on the level of efficiency of each individual structural element and its contribution to the overall level of police work efficiency.

In view of the above, we consider it necessary to note the "Procedure for assessing the level of public confidence in the National Police", which establishes a mechanism for assessing the level of public confidence in the police. Based on this mechanism, information is collected "on the assessment by the population of the quality of performance of bodies and units of the National Police assigned to them tasks and functions, on the compliance of the work of bodies and units of the National Police with the expectations of the population, identification of trends in the level

\footnotetext{
13 Осика I.M. Критерії оцінки ефективності діяльності правоохоронних органів: досвід США і Великобританії. Національна громадська платформа «Реформуємо МВС: прозорість та відповідальність». URL: http://police-reform.khpg.org/index.php?id=1433232742\&w=критерії оцінки (дата звернення: 04.12.2019).

14 Аброськін В.В. Особливості взаємодії Національної поліції України з іншими суб’єктами забезпечення публічної безпеки в умовах антитерористичної операції. Верховенство права у процесі державотворення та захисту прав людини в Украӥні : збірник матеріалів доп. учасн. Міжнар. наук.-практ. конф. Одеса : ГО Причорноморська фундація права, 2017. C. $46-54$.
} 
of public confidence in the National Police and the factors affecting them"15. In our opinion, such a legal act should be a starting point, an example for the legislative regulation of other directions, by which it will be possible in the aggregate to impartially evaluate the effectiveness of the police in Ukraine in the following objects: "The level of satisfaction of the population's need for police services; processes occurring in the National Police system and characteristics and results of its activities" ${ }^{\prime 6}$. The same legal act establishes two levels of assessing the level of public trust in the National Police: national and territorial, as well as the respective terms of holding the latter - at least once a year and, if necessary, respectively.

\section{Evaluation of police work during the united forces operations}

The specificity of the process of evaluating the work of the police, in terms of its effectiveness in the particular circumstances, in our case of the Joint Force Operation, influences both the direct organization of such evaluation by the relevant entities and the criteria by which it is conducted. This is influenced by the situation in the territory of the united forces operations: it has a negative impact on the ability of citizens to evaluate the work of one of the law enforcement agencies - the police, who make every effort to protect them, but because of their independent reasons cannot provide a total protection of citizens in this territory.

Thus, according to the United Nations, 10090 people (including 2777 civilians) have been killed and 23,966 injured since the start of the anti-terrorist operation to date (during the united forces operations) ${ }^{17}$. In addition, there have been frequent incidents of unreasonable detention and abduction of civilians, cases of ill-treatment, torture and sexual assault, coercion to forced labor, death (murder), robbery, extortion of money, destruction of property, kidnapping and humiliation.

In such extremely difficult conditions, police units must fulfill one of their main tasks - to ensure public safety (Paragraph 1 of Part 1 of Article 2 of the Law of Ukraine "On National Police"18, that is, a state of security

\footnotetext{
15 Порядок проведення оцінки рівня довіри населення до Національної поліції : Постанова КМУ від 07 лютого 2018 р. № 58. URL: https://zakon.rada.gov.ua/laws/show/58-2018-п (дата звернення: 21.01.2020).

16 Порядок проведення оцінки рівня довіри населення до Національної поліції : Постанова КМУ від 07 лютого 2018 р. № 58. URL: https://zakon.rada.gov.ua/laws/show/58-2018-п (дата звернення: 21.01.2020).

17 Чого варті права людини на терезах війни. Урядовий кур 'єp. URL: https://ukurier.gov.ua/ uk/articles/chogo-varti-prava-lyudini-na-terezah-vijni (дата звернення: 01.12.2019).

18 Про Національну поліцію: Закон України від 02 липня 2015 р. № 580-VIII. URL: https://zakon.rada.gov.ua/laws/show/580-19 (дата звернення: 22.01.2020).
} 
characterized by a high level and reliability of "vital for the state, society and every individual person's interests, rights, freedoms and citizens, which is a priority of the activity of each state body, local self-government body and their officials"19.

In this sense, we should agree with O. Panova, in whose opinion public safety "acts as an indicator of the atmosphere of peace of society, indicate the level of crime and efficiency of activity of state authorities and local self-government" 20 .

Thus, there is a directly proportional link between public security and police efficiency - the higher the public security status, the higher the corresponding level of evaluation of National Police performance, including from the point of view of the public, first and foremost, the police carry out their tasks, in particular ensuring public safety and order.

At the same time, the united forces operations on the territory of Ukraine is directly reflected on the population of the state, since under such conditions the aggressor, seeking to destabilize the situation in the territory and in the whole country, in order to ignite an internal conflict that will only benefit him, will guarantee the achievement of its goals and save resources through the use of information, moral, psychological measures of influence or other means of manipulating the population or discrediting public authorities - in first of all, law enforcement agencies, in particular the National Police. All these factors inevitably influence the formation of the public's views on the effectiveness of the police, and therefore must be taken into account when collecting primary information and processing it. However, even in the context of the united forces operations, the National Police show impressive results.

During assessing the effectiveness of the National Police's public security activities during the united forces operations, the following provisions should be relied upon:

Firstly, public opinion and the level of public trust in police forces (given that objective realities are not reflected in the united forces operations) can be neither a single nor a priority criterion for evaluating the effectiveness of police forces.

\footnotetext{
19 Батраченко О.В. Поняття та ознаки публічної безпеки та порядку як об'єктів адміністративно-правової охорони. Науковий вісник Ужгородського національного університету. Серія «Право». 2014. Вип. 29. Ч. 2. Т. 3. С. 84-86.

20 Панова О.О. Поняття, зміст і значення публічної безпеки і порядку. Науковий вісник Херсонського державного університету. Серія «Юридичні науки». 2016. Вип. 6. Т. 2. C. $133-136$.
} 
Secondly, the effectiveness of the united forces operations should be comprehensive, meaning that in the course of such activities, the following indicators should be identified and evaluated: public opinion about the job satisfaction or dissatisfaction with the work of the police and its level of confidence; statistics showing the crime rate within the territory of the united forces operations and the crime rate; information reflecting the professional and moral ethics of police personnel; information on the use of logistical resources by police; conclusions about the rationality and feasibility of management decisions; data on the quality of internal organizational work of police bodies and units; self-esteem, that is, data on how police officers provide daily security in the area of the united forces operations, evaluate their work and that of their colleagues, whether they can perform their duties even better and under what conditions; what they see as the shortcomings of the police in the united forces operations - all of this will allow to evaluate the effectiveness of the police not only from the outside but also from the inside.

In addition, during assessing the effectiveness of police work in the context of the united forces operations, it is urgent to take into account quantitative indicators, ie indicators related to the number of: identified persons who by their actions affect the territorial integrity and inviolability of the state, including those conducting anti-Ukrainian activities; seized weapons, ammunition and other objects of the permit system when trying to move them through filter points (checkpoints, checkpoints of entryexit); identified things that they have seized as a result of looting in the area of anti-terrorist operation, in particular when trying to export them from that area or transportation; proxies and agents who are part of the agency apparatus to provide police information in the context of an anti-terrorist operation, including their positive quantitative and qualitative dynamics; referrals of citizens residing in areas adjacent to the territory of an antiterrorist operation to the police authorities (including appeals to the Unified Analytical Service Center (UASC)) and civilians who, jointly with the police, ensure public security and order in the said territories, as a willingness to cooperate police is one of the criteria for citizens' trust; "Re-educated persons", those who initially exhibited deviant behavior and anti-patriotic sentiment but abandoned their anti-social views as a result of preventive measures implemented by the police.

Thirdly, to objectively evaluate the effectiveness of providing the National Police with public security in the context of the united forces operations, it is advisable to implement plans for the activities of police agencies with 
mandatory quantitative indicators, as well as to analyze information on the extent and completeness of such plans and implementation. strategies for the work of the police in the area of the united forces operations.

Fourthly, in this process, it is necessary to rely on empirical methods (observation, experiment, comparison, measurement, survey, description), when collecting the necessary data, and theoretical (analysis, synthesis, induction, deduction, etc.) - to obtain relevant conclusions on the effectiveness of the police.

Fifthly, there is a need to continue developing a regulatory framework governing the evaluation of police performance.

In view of the above, we believe that the process of evaluating police performance should take place at two levels: the first, which covered indicators of police performance throughout the state within the framework of the general tasks set before it, and the second, which would form an idea of police performance specific tasks in certain territories of the state, in particular during the conduct of an anti-terrorist operation or the establishment of other special legal regimes. This approach to determining the effectiveness of police operations requires appropriate regulation and the establishment of stable and specific criteria against which such assessment will be conducted.

At the first level, it is necessary to formulate a list of issues that should be covered in the process of carrying out the specified activity. The second level is a variational question, designed to take into account the specific activities of the services and units of the National Police in certain territories, including special legal regimes. In the latter case, questions should be formulated taking into account the political, economic and social conditions that influence the formation of the public's opinion about the work of the police, within certain territories.

According to the rules of Part 3 of Art. 11 of the Law of Ukraine "On National Police" 21 , p. 7 The procedure for assessing the level of public confidence in the National Police, approved by the Cabinet of Ministers of Ukraine from 07.02.2018 № 58, is within the competence of the police: determination of issues and terms by which the level of trust is conducted in accordance with the powers of the National Police, as well as an independent sociological service, which will carry out such an assessment and the degree of representativeness of social groups of the population ${ }^{22}$.

21 Про Національну поліцію: Закон України від 02 липня 2015 р. № 580-VIII. URL: https://zakon.rada.gov.ua/laws/show/580-19 (дата звернення: 22.01.2020).

22 Порядок проведення оцінки рівня довіри населення до Національної поліції : Постанова КМУ від 07 лютого 2018 р. № 58. URL: https://zakon.rada.gov.ua/laws/show/58-2018-п (дата звернення: 21.01.2020). 
The police also receive aggregate analytical information on the results of the evaluation to further integrate them into their work and prepare an appropriate report based on an analysis of the information obtained, which "informs the results of the evaluation on the official websites of the Ministry of Internal Affairs, National Police and other acceptable means"23.

In this context, we consider it necessary to attribute to the police authority the approval of lists of "permanent" and variational questions of the first and second categories, on the basis of which sociological researches will be conducted in order to determine the effectiveness of police work, especially in the context of anti-terrorist operation. In turn, the regulation of the criteria for evaluating the effectiveness of the police will make it impossible to falsify the results obtained at all levels, which will provide real data.

\section{Foreign experience evaluation of police activity}

Recently, the approach to assessing police work in developed countries has changed dramatically. This was facilitated by the spread of "public police" practices, which necessitated the assessment of the public's attitude to the police, the extension of the concept of new public management, which emphasized borrowing from corporate bodies (including the police) of corporate governance practices.

In this regard, police assessment models have become more complex and multifaceted ${ }^{24}$. It should be emphasized that there is no "ideal" model of assessment. Even in developed countries, there are ongoing discussions about the feasibility of certain approaches used to determine the effectiveness of law enforcement. In this regard, research of foreign experience in the field of police activity evaluation and identification of practices that are appropriate for use in police activity of Ukraine is of particular relevance.

As a result of the monitoring and evaluation of police work, international and domestic practices have identified a number of criteria for evaluating police performance. Consider the example of foreign countries: USA, UK, Canada, France, Scotland.

The United States of America lacks a unified police evaluation system. This is due to the peculiarities of the organization of the American police system. It is distinguished by an extremely high degree of decentralization, so there is no federal police force in the state (although there are a number

23 Про Національну поліцію: Закон України від 02 липн. 2015 р. № 580-VIII. URL: https://zakon.rada.gov.ua/laws/show/580-19 (дата звернення: 22.01.2020).

24 Бугайчук К.Л., Святокум I.О., Чумак В.В. Закордонний досвід оцінки ефективності поліцейської діяльності та перспективи його використання в Україні : науково-методичні рекомендації. Харків : Харк. нац. ун-т. внутр. справ, 2016. 52 с. 
of federal law enforcement agencies, such as the FBI). Each state has its own police authority, in addition, state-independent police and sheriff's departments operate locally and each uses its own evaluation system. The diversity of assessment systems is compounded by the fact that in the United States, there is an uneven distribution of powers between police agencies at different levels: in some states, state police perform only highway safety tasks, and in others, other police functions in territories not covered by the jurisdiction of municipal police. At the same time, most police functions in the United States are performed by local police departments that are formed, funded, and subordinate to local governments. As a rule, the activities of the police department are assessed within the department itself, although its results are submitted to local governments or specially created supervisory boards.

For example, in the USA, police evaluations focus on the following general indicators: the dynamics of crime, in particular its reduction; the number of arrested and detained; the number of crimes committed in relation to the recorded ones; the amount of time it takes the police to arrive on the call ${ }^{25}$. The list of general indicators, in turn, has taken on a more extensive form and combined criteria that actually relate to the priorities of police activity: 1) main tasks of the unit, interaction with other law enforcement agencies; 2) organization of the unit, management and administration activities; 3) structure of personnel; 4) organization of direct work with personnel; 5) operational activities; 6) support; 7) road safety activities; 8) detention and escorting activities; 9) support and technical services ${ }^{26}$.

In summary, it can be stated that in the USA considerable theoretical base and practical experience of evaluating police activity have been formed, but the system of evaluation of police activity as such is absent as of today. Despite the lack of systematic assessment of police at the national level, in the context of police reform in Ukraine, the United States' experience in developing and using law enforcement research methods is extremely interesting.

The police system of Canada, as in the USA, is complex. The state has a federal police force - the Royal Canadian Horse Police, and two provinces

25 Sparrow M.K. Measuring Performancein a Modern Police Organization. New Perspectivesin Policing. 2015. URL: https://www.ncjrs.gov/pdffiles1/nij/248476.pdf (дата звернення: 25.12.2019).

26 Осика І.М. Критерії оцінки ефективності діяльності правоохоронних органів: досвід США і Великобританії. Наџіональна громадська платформа «Реформуємо МВС: прозорість та відповідальність». URL: http://police-reform.khpg.org/index.php?id=1433232742\&w=критерії оцінки (дата звернення: 04.12.2019). 
(Ontario and Quebec) have separate police services; in addition, municipal police bodies have been set up in a number of cities. Accordingly, there are several police evaluation systems in the country, but, unlike in the United States, they are much more unified. The results of the work of the Federal Police Authority, the Canadian Royal Horse Police, are evaluated first and foremost in the context of the achievement of strategic goals, each of which is specified by the relevant budget programs. This practice is characteristic of other state authorities and is based on a methodology of a balanced scorecard.

Canadian provincial law provides the operation of police commissions, which are formed in cities to oversee the activities of municipal police. Police commissions in Canada have a slightly wider range of responsibilities and tasks than their American counterparts. This is also reflected in the fact that the evaluation of the activities of local police units is mainly carried out by police commissions. The valuation models used by them, as in the US, differ significantly. As a rule, larger police units use more sophisticated and informative assessment models. In particular, the areas where police work is most often evaluated is to reduce victimization, to ensure that offenders are held accountable, to reduce their fear of crime and to increase their sense of security, to ensure safety in public places, to effectively, equitably and lawfully use police influence, effective and appropriate. use of financial resources, $\operatorname{etc}^{27}$. However, both police statistics and external sources can be used.

There is no single police service in the UK. Instead, the territories are served by 43 independent police services. In addition, Scotland and Northern Ireland have their own police forces. According to the 1996 Police Act, the principal body responsible for evaluating police work in England and Wales is the Police Inspectorate ${ }^{28}$ (There is a separate Police Inspectorate in Scotland; this authority conducts an inspection upon request in Northern Ireland). This body is one of four law enforcement inspections (the other three are the Prosecutor's Office, the Probation Inspectorate, and the Prison Inspectorate).

In the UK, police performance is assessed in two dimensions: on the one hand, comparing police units in terms of compliance with state-

\footnotetext{
27 Даниленко Ю.С. Оцінювання у державній службі: теорія і правове регулювання : дис. ... канд. юрид. наук : 12.00 .07 / Національний ун-т «Одеська юридична академія». Одеса, 2017. 212 с.

28 Панова О.О. Поняття, зміст і значення публічної безпеки і порядку. Науковий вісник Херсонського державного університету. Серія «Юридичні науки». 2016. Вип. 6. Т. 2. C. $133-136$.
} 
level performance standards, and on the other, the implementation by local units of specific planning documents adopted at the local level, taking into account the specific socio-economic development, criminogenic situation, etc. Such an approach seems quite feasible for implementation in Ukraine. On the one hand, it ensures the unification of the activities of the territorial bodies of the National Police, comparison of the results of their activities and compliance with certain national standards. On the other hand, it will provide Ukraine with a course on decentralization of public power and adaptation of police activities to specific local conditions.

Also, a generalized assessment of the police work units is carried out annually by a special method, according to which the established indicators are subject to evaluation: 1) effectiveness, which is determined by finding out the completeness of tasks assigned to a particular unit or police body (for example, in the following areas: "crime prevention, antisocial behavior and ensuring the safety of the population; crime investigation; protection of vulnerable categories of people and work with victims of crime; work on combating serious and organized crime"29); 2) expediency, which demonstrates the rationality and effectiveness of the use of available resources, including financial resources, by the police; 3) legitimacy, by which the level of public trust in the police is determined, as well as communication with the public.

Thus, the UK police evaluation system combines: 1) a decentralized approach that takes into account the expectations and wishes of local communities; 2) a centralized approach that enables the state to effectively implement law enforcement policies; 3) the complexity of the assessment, allowing researchers to relate the police assessment system in England and Wales to best international practice in the field ${ }^{30}$.

In addition, in cities of Scotland, in particular in Edinburgh, a measure has been put in place to measure the achievement of the goals set out in the future work plans of police units. Each plan outlines its own topical goals to be achieved for the period covered by the plan: reducing crime and public order, including aggravated circumstances (for example, committing them intoxicated); interaction with the administration of public events to ensure the safety of visitors; reducing the number of accidents with

\footnotetext{
29 Святокум I.О. Досвід функціонування системи оцінки діяльності поліції Великобританії та перспективи його використання в Україні. Науковий вісник публічного та приватного права. 2016. Вип. 3. С. 186-189.

30 Круглова А.Є. Адміністративно-правові засади оцінювання ефективності діяльності органів та установ виконання покарань : дис. ... канд. юрид. наук : 12.00 .07 / Харківський національний університет внутрішніх справ. Харків, 2016. 277 с.
} 
serious and fatal consequences; combating drug offenses and encroachment on private property ${ }^{31}$. In contrast, the London police work plan contains quantitative benchmarks to be achieved by police: crime reduction $-20 \%$; savings in financial security - $20 \%$; increase of citizens' trust - about $70 \%$; reduction of reoffending by teenagers $-20 \%{ }^{32}$.

In contrast to the above countries, the French police system is highly centralized, which is reflected in its evaluation system. The police, like many other public authorities, is evaluated first and foremost to determine the extent to which the government is tasked with it (known as ministerial missions). Herewith, the French approach to police evaluation is primarily focused on the efficiency of its use of budgetary resources. Yes, the police performance report and project activity for the next year (as well as other state authorities) is added to the draft budget; these documents are justification for budgetary purposes.

Together with other bodies under the Ministry of Internal Affairs of France (above all, the gendarmerie), the French National Police work within the framework of the Ministerial Security Mission, and its actions are specified in the National Police Program. In particular, in the plan for the year, its main directions are to ensure: public order and sovereignty; security and public peace; road safety; combating illegal migration and security of international transport routes; accomplishing the tasks of the judicial police and facilitating the administration of justice; management, human and material resources ${ }^{33}$.

Investigating the criteria of the police effectiveness of foreign countries A. Serdyuk made the following conclusions: firstly, the evaluation of the effectiveness of police activity in foreign countries is carried out, for the most part, on two parameters - quantitative and qualitative; secondly, the quantitative indicators differ depending on the particular activities of each country; thirdly, in most countries, police performance is measured by the achievement of the goals set out in the strategic plans for a defined period; fourthly, the mandatory component of the effectiveness of police activity is the use of budgetary funds and other proceeds for law enforcement

31 Scotland Annual Policing Plan 2014|2015. Scotland. police. uk. URL: http://www.scotland. police.uk/assets/pdf/138327/150739/policescotlandannualpoliceplan2014-15?view=Standard (дата звернення: 25.12.2019).

32 Police and Crime Plan 2017/2021. London.gov.uk. URL: https://www.london.gov.uk/mopac-publications/police-and-crime-plan-2017-2021 (дата звернення: 25.12.2019).

33 Охріменко І.М. Оцінка ефективності діяльності органів і підрозділів Національної поліції України: погляд на проблему. Підприємництво, господарство і право. 2016. № 11. C. $139-144$. 
activities; fifthly, an important element of the evaluation of police activity abroad is the conduct of sociological surveys of the population on the evaluation of police work, improving public safety and a sense of protection of his rights and interests ${ }^{34}$.

It should be noted that during the evaluation of police activity in foreign countries (experience of the USA, United Kingdom, France, Canada, Scotland), public opinion, becoming an important component and a kind of reference, does not play a decisive role, and the main place is proportional combination as quantitative, and quality indicators of police work.

Given the foreign experience of evaluating the activities of the Ukrainian police, it is possible not only for the police, but for external, independent services, both established by the state and local governments. After all, at the national level in Ukraine such services can be created either within the Ministry of Internal Affairs of Ukraine, or organizationally subordinate to it. At the local level, the functions of assessing the activities of the units of the National Police may be performed by local governments or police commissions, whose activities are already provided for by the Law of Ukraine "On the National Police".

\section{CONCLUSIONS}

The evaluation of the effectiveness of the National Police's public security activities during the united forces operations should be based on the following provisions: firstly, public opinion and the level of public trust in the police are an objective criterion for evaluating the effectiveness of police units; secondly, the assessment of effectiveness in the context of the united forces operations must be comprehensive; thirdly, compulsory accounting of police performance; fourthly, implement plans for the activities of police units regarding the extent and completeness of their implementation in the area of the united forces operations; Fifthly, to rely on empirical and theoretical methods; sixthly, to continue developing a regulatory framework governing the evaluation of police effectiveness; seventhly, to evaluate the performance of police officers with the mandatory coverage of police performance indicators throughout the country and during the conduct of the united forces operations or other special legal regimes; eighthly, taking into account foreign experience of evaluating police activity

\footnotetext{
34 Сердюк А.М. Щодо критеріїв ефективності діяльності поліції закордонних країн. Науковий вісник Херсонського державного університету. Серія «Юридичні науки». 2015. Вип. 3-2. Т. 2. С. 155-159.
} 
not only by police bodies but also by external, independent services, both established by the state and local self-government bodies.

\section{SUMMARY}

The article is devoted to the study of performance evaluation of the National Police of Ukraine in providing public security in the context of the operation of the United Forces. Theoretical approaches to determining the category of "efficiency" and "efficiency of public administration" are investigated. The indicators (components) of the performance evaluation of the units of the National Police of Ukraine are analyzed. Research methods - empirical, such as observation, experiment, comparison, measurement, questioning, description and theoretical - analysis, synthesis, induction, deduction are considered. It is determined that in extremely difficult conditions, police units must provide public security, in accordance with the Law of Ukraine "On National Police", as one of their main tasks. It has been shown that there is a direct correlation between public safety and police efficiency. It is suggested to carry out the process of evaluating the effectiveness of police work by covering indicators of police effectiveness throughout the country and when performing specific tasks for the police. Overseas police experience in countries such as the United States of America, United Kingdom, France, Canada, Scotland has been analyzed, and it has been established that evaluating policing is done by combining qualitative indicators of police work.

\section{REFERENCES}

1. Про Національну поліцію: Закон України від 02 липня 2015 p. № 580-VIII. URL: https://zakon.rada.gov.ua/laws/show/580-19 (дата звернення: 22.01.2020).

2. Порядок проведення оцінки рівня довіри населення до Національної поліції : Постанова КМУ від 07 лютого 2018 р. № 58. URL: https://zakon.rada.gov.ua/laws/show/58-2018-п (дата звернення: 21.01.2020).

3. Аброськін В.В. Особливості організації служби на блокпостах у зоні антитерористичної операції. Науковий вісник публічного та приватного права. 2018. Вип. 5. С. 125-129.

4. Адміністративна діяльність Національної поліції: навчальний посібник / Т.П. Мінка та ін. Дніпро : Дніпроп. держ. ун-т внутр. справ, 2017. $248 \mathrm{c}$.

5. Адміністративна діяльність органів внутрішніх справ. Загальна частина : навчальний посібник / В.В. Середа та ін. Львів : Львів. держ. ун-т внутр. справ, 2015. 511 с. 
6. Батраченко О.В. Поняття та ознаки публічної безпеки та порядку як об'єктів адміністративно-правової охорони. Науковий вісник Уэсгородського національного університету. Серія «Право». 2014. Вип. 29. Ч. 2. Т. 3. С. 84-86.

7. Бугайчук К.Л., Святокум I.О., Чумак В.В. Закордонний досвід оцінки ефективності поліцейської діяльності та перспективи його використання в Україні : науково-методичні рекомендації. Харків : Харк. нац. ун-т. внутр. справ, 2016. 52 с.

8. Великий тлумачний словник сучасної української мови / уклад. і голов. ред. В.Т. Бусел. Київ ; Ірпінь : Перун, 2009. 1736 с.

9. Даниленко Ю.С. Оцінювання у державній службі: теорія і правове регулювання : дис. ... канд. юрид. наук : 12.00.07 / Національний ун-т «Одеська юридична академія». Одеса, 2017. 212 с.

10. Круглова А.С. Адміністративно-правові засади оцінювання ефективності діяльності органів та установ виконання покарань : дис. ... канд. юрид. наук : 12.00.07 / Харківський національний університет внутрішніх справ. Харків, 2016. 277 с.

11. Маліков В.В. Адміністративно-правові форми забезпечення громадського порядку. Серія Право. 2014. Вип. 28. Т. 2. С. 144-147.

12. Мартиненко О., Захаров С. Стратегія розвитку органів внутрішніх справ. Закон і Бізнес. URL: http://zib.com.ua/ua/print/101834-strategiya_ rozvitku_organiv_vnutrishnih_sprav_tekst_proektu.html (дата звернення: 01.12.2019).

13. Осика І.М. Критерії оцінки ефективності діяльності правоохоронних органів: досвід США i Великобританії. Начіональна громадська платформа «Реформуємо МВС: прозорість та відповідальність». URL: http://police-reform.khpg.org/index.php?id=1433232742\&w=критерії оцінки (дата звернення: 04.12.2019).

14. Основи методології та організації наукових досліджень : навчальний посібник / за ред. А.С. Конверського. Київ : Центр навч. літ., 2010. 352 с.

15. Охріменко І.М. Оцінка ефективності діяльності органів і підрозділів Національної поліції України: погляд на проблему. Підприємництво, господарство і право. 2016. № 11. С. 139-144.

16. Панова О.О. Поняття, зміст і значення публічної безпеки і порядку. Науковий вісник Херсонського державного університету. Серія «Юридичні науки». 2016. Вип. 6. Т. 2. С. 133-136.

17.Пчелін В.Б. Сутність інформаційного забезпечення адміністративного судочинства України. Науковий вісник Ужгородського національного університету. Серія «Право». 2016. Вип. 3. Т. 2. С. 22-25.

18. Рассоха I.M. Методологія та організація наукових досліджень: конспект лекцій. Харків : Харків. нац. акад. міськ. госп-ва, 2011. 76 с. 
19. Святокум І.О. Досвід функціонування системи оцінки діяльності поліції Великобританії та перспективи його використання в Україні. Науковий вісник публічного та приватного права. 2016. Вип. 3. С. 186-189.

20. Сердюк А.М. Щодо критеріїв ефективності діяльності поліції закордонних країн. Науковий вісник Херсонського державного університету. Серія «Юридичні науки». 2015. Вип. 3-2. Т. 2. С. 155-159.

21. Ткачова О.К. Ефективність державного управління: поняття та підходи до оцінювання. Вісник Національної академії державного управління при Президентові України. 2013. № 2. С. 30-37. URL: http://nbuv.gov.ua/ UJRN/Vnadu_2013_2_6 (дата звернення: 26.12.2019)

22. Чого варті права людини на терезах війни . Урядовий кур'єр. URL: https://ukurier.gov.ua/uk/articles/chogo-varti-prava-lyudini-na-terezah-vijni (дата звернення: 01.12.2019).

23. Police and Crime Plan 2017/2021. London.gov.uk. URL: https://www.london.gov.uk/mopac-publications/police-and-crimeplan-2017-2021 (дата звернення: 25.05.2018).

24. Scotland Annual Policing Plan 2014|2015. Scotland.police.uk. URL: http://www.scotland.police.uk/assets/pdf/138327/150739/policescotlandannua lpoliceplan2014-15?view=Standard (дата звернення: 25.05.2018).

25. Sparrow M. K. Measuring Performance in a Modern Police Organization. New Perspectives in Policing. 2015. URL: https://www.ncjrs.gov/pdffiles1/nij/ 248476.pdf (дата звернення: 25.12.2019).

Information about the author: Abroskin V. V., Doctor of Law, Rector Odesa State University of Internal Affairs 1, Uspenska street, Odessa, Ukraine

DOI https://doi.org/10.30525/978-9934-588-43-3/1.13 